To Cite: Güler E, Durhasan T, Karasu İ, Akbıyık H, 2021. Passive Flow Control around NACA 0018 Airfoil Using Riblet at Low Reynolds Number. Journal of the Institute of Science and Technology, 11(3): 2208-2217.

\title{
Passive Flow Control around NACA 0018 Airfoil Using Riblet at Low Reynolds Number
}

\section{Emre GÜLER ${ }^{1}$, Tahir DURHASAN ${ }^{2 *}$, İlyas KARASU², Hürrem AKBIYIK ${ }^{3}$}

\begin{abstract}
In this study, aerodynamic capabilities of NACA 0018 airfoil is numerically investigated by installing riblet on the suction side of airfoil. Numerical results were obtained by ANSYS Fluent using k-kl-kw transition model at Reynolds number of $\mathrm{Re}=100$ 000. Three different riblet airfoil configuration was performed at six different angles of attack $\left(\alpha=8^{\circ}, 10^{\circ}, 13^{\circ}, 15^{\circ}, 17^{\circ}\right.$ and $\left.19^{\circ}\right)$ and these results compared with the clean model. For M1 model the riblet was located at chord wise section of $x / c=0.3$ while it installed at $x / c=0.7$ for $M 2$ model. For M3 model two riblets were used and they were located at both $\mathrm{x} / \mathrm{c}=0.3$ and $\mathrm{x} / \mathrm{c}=0.7$. Obtained numerical result show that the use of riblet remarkably affects the flow characteristics of airfoil. At $\alpha=8^{\circ}$ the $C_{L} / C_{D}$ value of $M 1$ model is increased by $4.5 \%$ when compared to clean model. It is indicated that angle of attack at $\alpha=10^{\circ}$, lift coefficient is increased for all models with compared to clean model. Stall angle is delayed from $\alpha=13^{\circ}$ to $\alpha=15^{\circ}$ at M1 and M3 with compared to clean model and lift coefficient is increased about $37 \%$ because of the restriction of the laminar separation bubble and trailing edge separation.
\end{abstract}

Keywords: Low Reynolds Number, NACA 0018 airfoil, Riblet, Passive flow control

\footnotetext{
${ }^{1}$ Emre GÜLER (Orcid ID: 0000-0001-7337-8678), Tarsus Üniversitesi, Havacılık ve Uzay Bilimleri Fakültesi, Havacılık ve Uzay Mühendisliği Bölümü, Mersin, Türkiye

${ }^{2 *}$ Tahir DURHASAN (Orcid ID: 0000-0001-5212-9170), İlyas KARASU (Orcid ID: 0000-0003-3138-6236), Adana Alparslan Türkeş Bilim ve Teknoloji Üniversitesi, Havacılık ve Uzay Bilimleri Fakültesi, Havacılık ve Uzay Mühendisliği Bölümü, Adana, Türkiye

${ }^{3}$ Hürrem AKBIYIK (Orcid ID: 0000-0002-1880-052X), Çukurova Üniversitesi, Mühendislik Fakültesi, Makine Mühendisliği, Adana, Türkiye

* Corresponding Author: Tahir DURHASAN, e-mail: tdurhasan@atu.edu.tr
}

The article was presented as an oral presentation at the "International Conference on Energy, Environment and Storage of Energy" held in Kayseri on 19-21 November 2020. 


\section{INTRODUCTION}

Flow regimes with Reynolds number of less than 500000 are called as low Reynolds number flows (Yarusevych et al., 2009). In low Reynolds number flows, separated flow due to the smaller inertia forces compared to the viscous forces in the laminar flow over the wing, is transferred to turbulent flow and then it is reattached to the surface. The region between the separation and reattachment point is called the laminar separation bubble (LSB). The laminar separation bubble has adverse effects on aerodynamic performance of airfoil, such as vibration, noise and decrease in the lift coefficient, etc. In practice, the effect of laminar separation bubble is clearly observed in vertical axis wind turbines (VAWT) and micro aerial vehicles. Many researchers performed investigation on the laminar separation bubble and effects of laminar separation (Ricci and Montelpare, 2005; Zhang et al., 2008; Genç et al., 2012; Janmian et al., 2013; Demir and Genç, 2017). In addition to these studies, extensive study on wing aerodynamics in low Reynolds numbers was carried out by Genç et al. (2012).

Many active and passive flow control methods have been using in order to suppress laminar separation bubble. Passive flow control methods are cheaper and simpler than active flow control methods.

One of the passive flow controls is to create roughness surface. Koca et al. (2016) performed passive flow control experimentally with sandpaper as a rough surface on NACA 4412 wind turbine blade. The hot-wire and smoke-wire is experimented at $\alpha=8^{\circ}$ and range of 25000 and 75000 which is low Reynolds number flows region. Sandpaper is installed at the $15-25 \%$ of chord with $0.5 \mathrm{~mm}$ thickness. As a result of this study they observed that the size and location is changed with increased lift. Fatehi et al. (2019) studied on wind turbine blade numerically on Riso_B1_18 airfoil with notable aerodynamic performance for wind turbine blade by applied optimized cavity surface on airfoil. They showed that the cavity covers the vortex for controlling stall, arrests flow fluctuations and seriously expand on $C_{L} / C_{D}$ ratio with out of design criteria. They also measured lift and drag forces in a wind tunnel to validate numerical results with and without optimized cavity and it is showed that the lift-todrag ratio is increased with $31 \%$ and $57 \%$ at $\alpha=14^{\circ}$ and $\alpha=20^{\circ}$, respectively. NACA 0012 wing profile with a micro riblet surface in the range of Reynolds Number, $10300 \leq \mathrm{Re} \leq 51400$ experimentally studied by Lee and Jang (2005). As a result of this study, $C_{D}$ decreased by $6.6 \%$ at $R e=10300$. However, at $\mathrm{Re}=51400$, the $C_{D}$ increased due to the fact that the riblet surface created small-scale vortices. Sefiddashti et al. (2018) experimentally studied drag reduction with riblet on Ris $\varnothing$ airfoil. As a result of this study, they found that the shear stress close to airfoil decreased with riblet valley on the wing at $\alpha=7^{\circ}$ and decreased by $29.7 \%$ in $C_{D}$ at $\operatorname{Re}=202000$ and $54 \%$ at $\operatorname{Re}=140000$. Rinoie et al. (2009) assembled a slim plate over the near of leading edge of NACA 0012 at $\mathrm{Re}=130000$ to control LSB and they found that the small bubble and stall is repressed by slim plate. They experimentally studied with flow visualization test and surface pressure measurement. This study showed that the stall angle and the maximum lift coefficient are increased. Seshagiri et al. (2009) experimentally showed that the suppression of LSB and reduction size of LSB by using vortex generator. They studied with six different static vortex generator configurations were examined with surface flow visualization and force balance measurements. They also remarked that the lift coefficient increased up to $\% 25$ at $\mathrm{Re}=160000$ for NASA/Langley LS(1)-0417 GA(W)-1 airfoil. Slots installed on leading edge on NACA 4412 airfoil investigated by Beyhangi and Amono (2018) at Reynolds number, Re=1 600000. They found the best result at $\alpha=6^{\circ}$ to $\alpha=8^{\circ}$ after examination of several slot and angle of attack configurations. Caram and Ahmed (1992), Han et al. (2003) studied about riblet on airfoil with symmetric or non-symmetric airfoils studied by Sareen et al. (2011) and Chamorro et al. (2013). Closely 
$16 \%$ drag reduction is observed by Sundaram et al. (1996) for symmetric airfoils and also 4-6\% drag reduction with non-symmetric airfoil.

The purpose of this numerical study is to enhance lift coefficient, lift to drag ratio and suppress laminar separation bubble by using riblet over NACA 0018 symmetrical airfoil. Six different angles of attack and three different riblet cases were carried out to obtain best case for aerodynamic performance at $\operatorname{Re}=100000$ with structural mesh. Numerical solutions were also performed for clean airfoil in order to show the effect of riblet, clearly. Instalization of riblet on the upper surface of airfoil can effect the aerodynamic character of NACA 0018 airfoil with the subduing LSB.

\section{MATERIALS AND METHODS}

In the present numerical study was performed with ANSYS Fluent 18.1 solver. The C type mesh is created with ICEM CFD. Center of arc is located to trailing edge of NACA 0018 airfoil and arc is set up with 10c radius, domain extends $20 \mathrm{c}$ along $\mathrm{x}$-direction from trailing edge as shown in Figure 1 . Flow input is given as pressure-far-field and airfoil surface is set up as wall boundary condition with no slip condition.

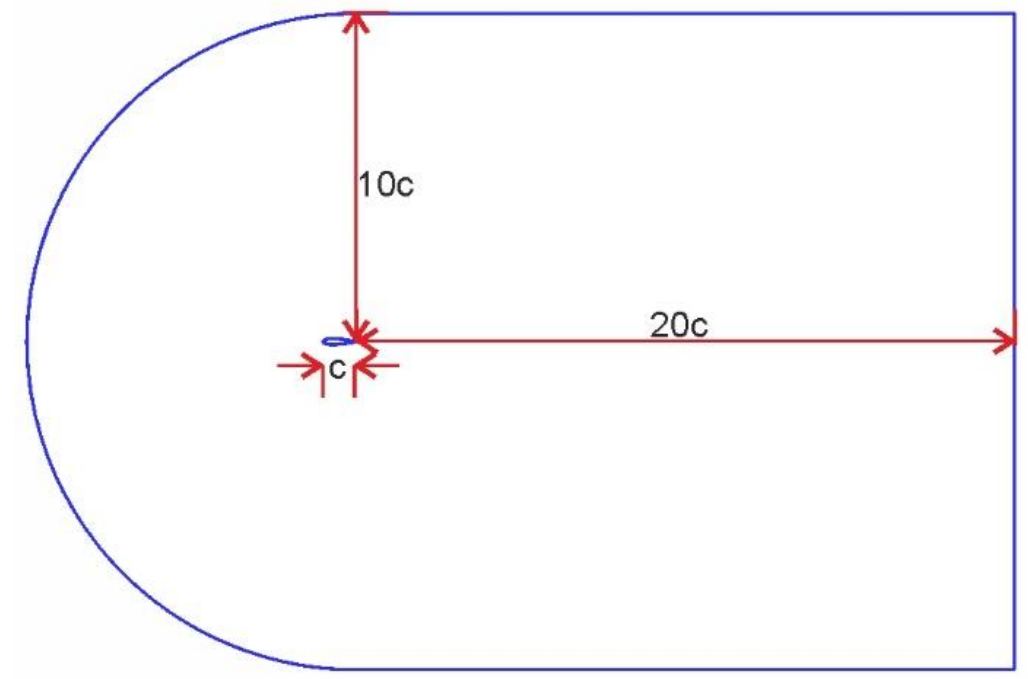

Figure.1. Flow domain and sizes

The structural mesh is applied with $y+$ value is less than 1 to have better boundary layer results. Figure 2 shows the general view of structured mesh and close side of airfoil and riblet mesh.

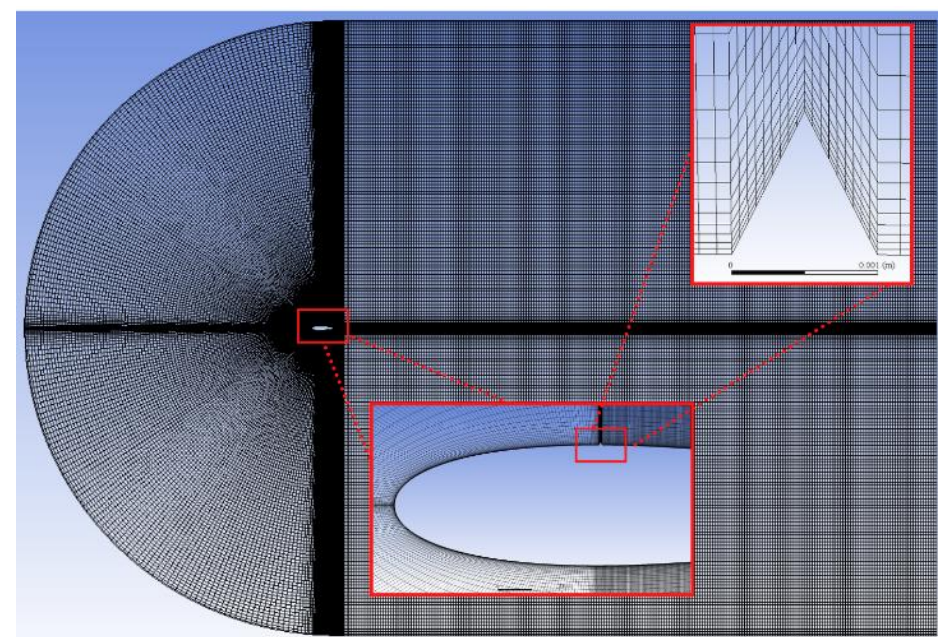

Figure.2. General view of structured mesh of domain, airfoil and riblet

Reynolds number, lift coefficient, drag coefficient and pressure coefficient are determined with formulas given below. 


$$
\begin{aligned}
R e & =\frac{\rho U c}{\mu} \\
C_{L} & =\frac{F_{L}}{\frac{1}{2} \rho U^{2} S} \\
C_{D} & =\frac{F_{D}}{\frac{1}{2} \rho U^{2} S} \\
C_{P} & =\frac{\Delta P}{\frac{1}{2} \rho U^{2}}
\end{aligned}
$$

In these equations, $c$ means to chord of the airfoil, $\mu$ means to dynamic viscosity of air, $F_{L}$ means to lift force, $F_{D}$ means to drag force, $U$ means to free-stream velocity, $\rho$ means to density of air, $S$ represents projection range of the airfoil and $\Delta \mathrm{P}$ means to pressure differences between airfoil surface and free-stream velocity. To make better comparison, $\mathrm{C}_{\mathrm{P}}$ is used with negative sign.

Steady state solutions with second order discretization and implicit formulation were applied. One of turbulence model is used to get better solution for transitional flow that which is $\mathrm{k}-\mathrm{kl}-\mathrm{k} \omega$ model, and it is showed that the best model for laminar to turbulence transition with previous study from Walters and Leylek (2004). Reynolds number is kept at 100000 based on chord length of airfoil. Triangle riblet assembled on suction side of NACA 0018. Riblet size with height (h) and width (w) is set to $1 \mathrm{~mm}$. Three different riblet airfoil configurations were analyzed at four different angle of attacks $\left(\alpha=8^{\circ}, 10^{\circ}\right.$, $13^{\circ}, 15^{\circ}, 17^{\circ}$ and $19^{\circ}$ ).

For M1 model the riblet was located at chord wise section of $\mathrm{x} / \mathrm{c}=0.3$ while it is installed at $\mathrm{x} / \mathrm{c}=0.7$ for M2 model. For M3 model two riblets were used and they were located at both $\mathrm{x} / \mathrm{c}=0.3$ and $\mathrm{x} / \mathrm{c}=0.7$. Schematic representation of airfoil with the riblet and examined parameters are shown in Figure 3.

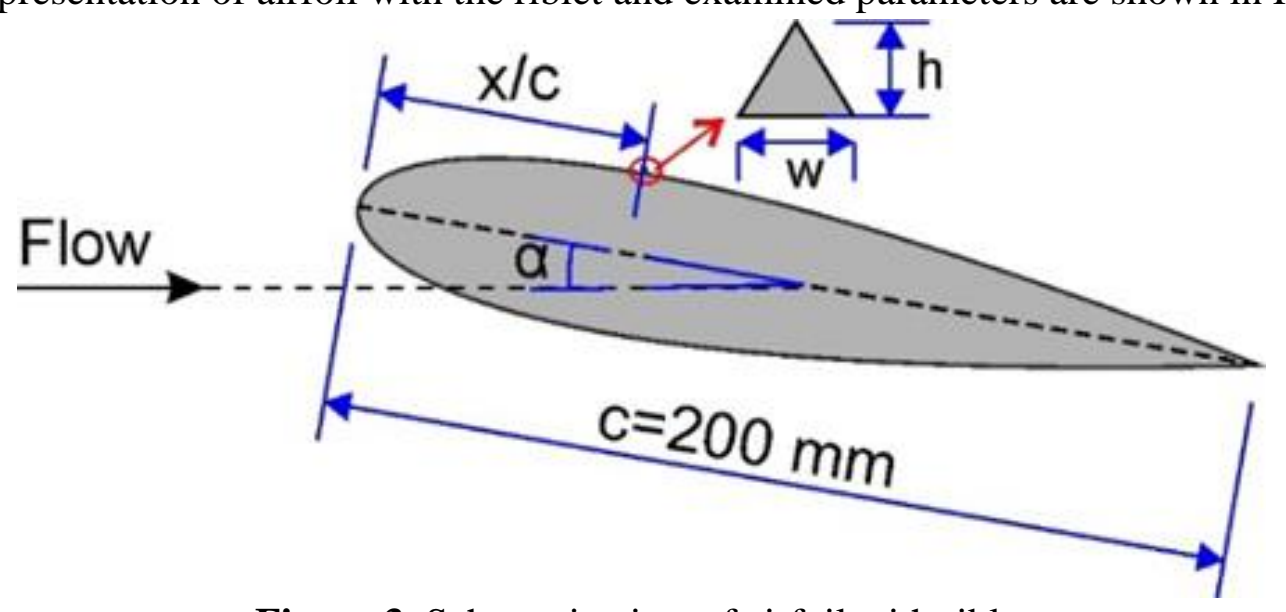

Figure 3. Schematic view of airfoil with riblet

First of all, clean NACA 0018 airfoil is analyzed to validate numerical solution with experimental datas. Figure 4 presents variation of $C_{L}$ with the angle of attack obtained from numerical solution and experimental data of Istvan et al. (2017). It is clearly seen that obtained the values of $C_{L}$ are good agreement with experimental data. 


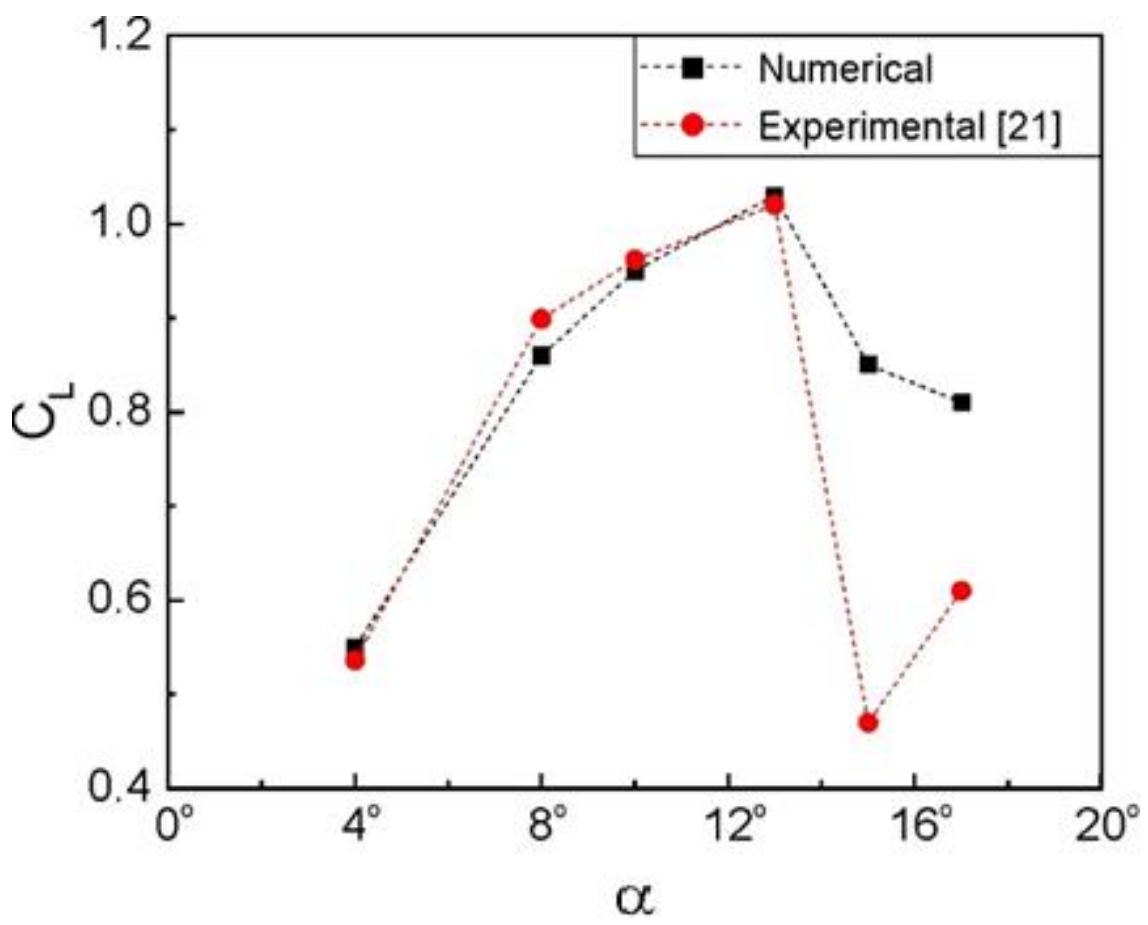

Figure 4. Validation of lift coefficient with experimental data Mesh Independence Study

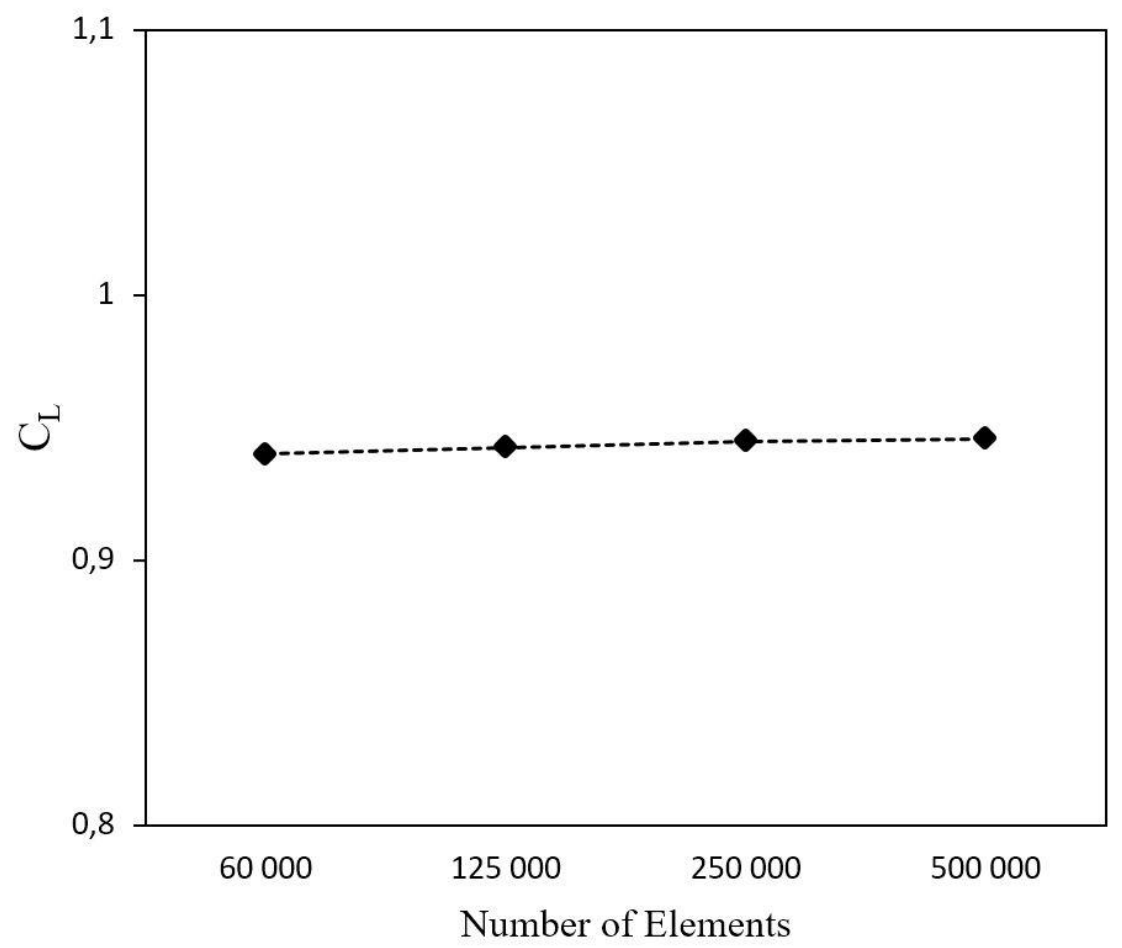

Figure 5. Mesh independence study for NACA 0018 at $\mathrm{Re}=100000$ and $\alpha=10^{\circ}$

In order to show the mesh independence of numerical solutions, the flow around NACA 0018 at $\alpha=10^{\circ}$ value of the airfoil attack angle (uncontrolled state) solution was realized in 4 different cell numbers and the change of lift coefficient with different node numbers $\mathrm{C}_{\mathrm{L}}$ is presented in Figure 5. The results obtained showed that the number of 250000 cells were sufficient and also the $y+$ value was found below 1 in this cell number. In addition, attention has been paid to keep the y+ value below 1 in all numerical solutions where the control method is applied. 


\section{RESULTS AND DISCUSSION}

The variations of $C_{L}$ with the angle of attack are presented in Figure 6 for all models. As seen from the figure, it is observed that riblet is insignificant effect on the lift coefficient for all models at low angle of attack. The value of lift coefficients are nearly same for all models at $\alpha \leq 10^{\circ}$. Stall angle of clean model is determined as $\alpha=13^{\circ}$. It is observed that clean and M2 model have same trend. However, at M1 and $\mathrm{M} 3$, stall angle is delayed to $\alpha=15^{\circ}$ in comparison with the clean model. $\mathrm{C}_{\mathrm{L}}$ is increased at M1 and M3 around $37 \%$ compared with clean and M2 at $\alpha=15^{\circ}$.

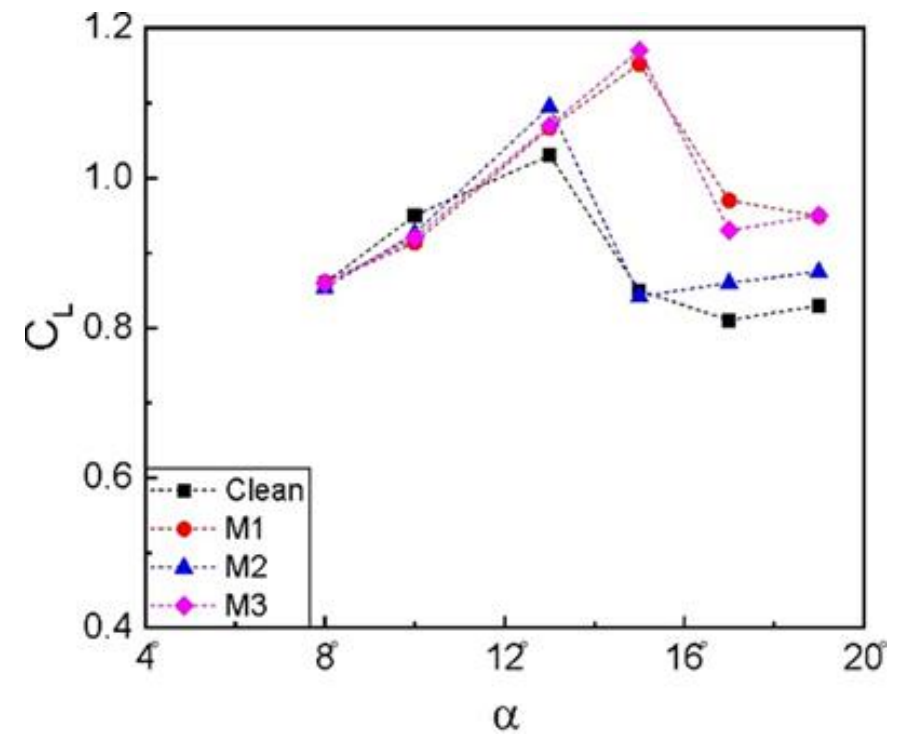

Figure 6. The variations of lift coefficient with the angle of attack for all models

One of the important aerodynamics parameter is determination lift to drag ratios. At Figure 7 , change of $C_{L} / C_{D}$ are showed with different angle of attack for all model. At $\alpha=8^{\circ}$ the $C_{L} / C_{D}$ value of $M 1$ model is increased by $4.5 \%$ when compared to clean model. On the other hand, the $\mathrm{C}_{\mathrm{L}} / \mathrm{C}_{\mathrm{D}}$ values of $\mathrm{M} 2$ and M3 are lower than clean airfoil. It is seen that the values of $C_{L} / C_{D}$ are nearly same at $\alpha=13^{\circ}$ for all model. However, $\mathrm{C}_{\mathrm{L}} / \mathrm{C}_{\mathrm{D}}$ value of $\mathrm{M} 2$ is more than $\mathrm{M} 1, \mathrm{M} 3$ and clean model about $10 \%$. It should be pointed out even for M1 and M3 model, the values of $C_{L} / C_{D}$ are higher than the other models due to the delaying the stall. It is found that $\mathrm{C}_{\mathrm{L}} / \mathrm{C}_{\mathrm{D}}$ ratios are 4.16, 12.8, 4.19 and 13.7 at clean, M1, M2 and M3 at $\alpha=15^{\circ}$, respectively. For all models, the values of $C_{L} / C_{D}$ are nearly same for all models at $\alpha>15^{\circ}$.

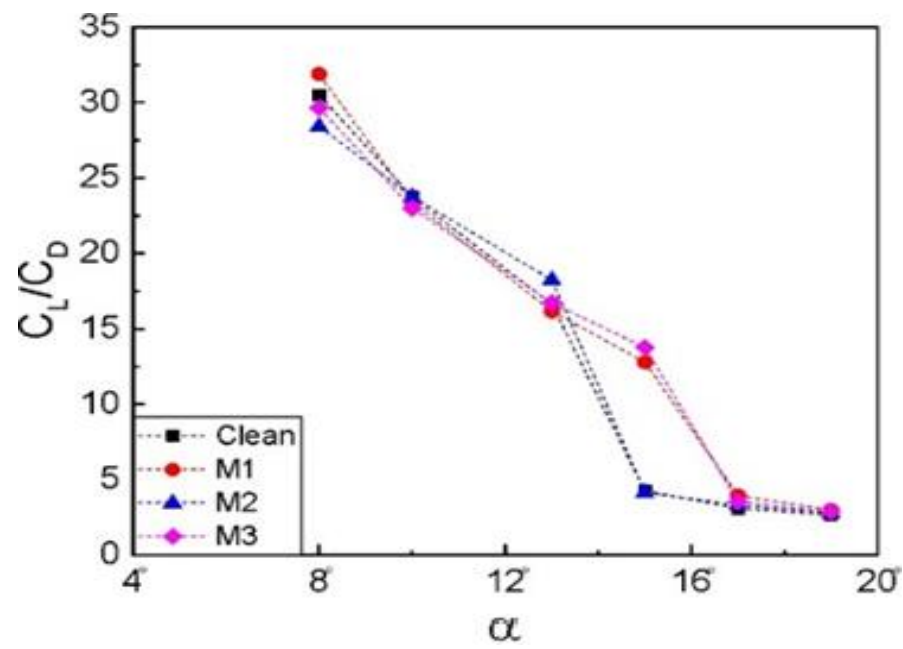

Figure 7. The variations of lift-to-drag ratio with the angle of attack for all models 
Figure 8 is given to show pressure coefficient distribution over airfoil at $\alpha=8^{\circ}, 10^{\circ}, 13^{\circ}$ and $15^{\circ}$ for clean, M1, M2 and M3. Distribution of pressure coefficient is an important parameter to determine flow characteristic around the airfoil. The humps in the curves indicate that formation of laminar separation bubble while downward movement of the curve indicates the transition of the flow to turbulence. As can be seen from Figure 8, riblet placed over suction side of airfoil least to decreases in the size of LSB for $\mathrm{M} 1$ and $\mathrm{M} 3$. It is found that $-\mathrm{C}_{\mathrm{P}}$ increases with increase in angle of attack and it causes lift enhancement.

The Figure 9 presents streamline topologies and stream-wise velocity contours to show flow structure of clean NACA 0018 airfoil. As seen from the Figure 9, at $\alpha=8^{\circ}$, laminar separation bubble (designated with LSB in the figure) and trailing edge separation (designated with TES in the figure) are formed on the upper side of airfoil. It is observed that LSB and TES move towards to in front of the airfoil with the increased angle of attacks. At $\alpha=13^{\circ}$, trailing edge separation is enlarged with compared to $\alpha=8^{\circ}$ to $\alpha=10^{\circ}$. At $\alpha=15^{\circ}$, a large recirculation region designated with $F$ in the figure indicates formation of stall. Stream-wise velocity contours show that the increase in angle of attack, reverse flow is grown along suction side of airfoil until $\alpha=15^{\circ}$. At $\alpha=15^{\circ}$, stream-wise velocity contours indicate that the reverse flow covers all suction surface of airfoil and stall takes place.
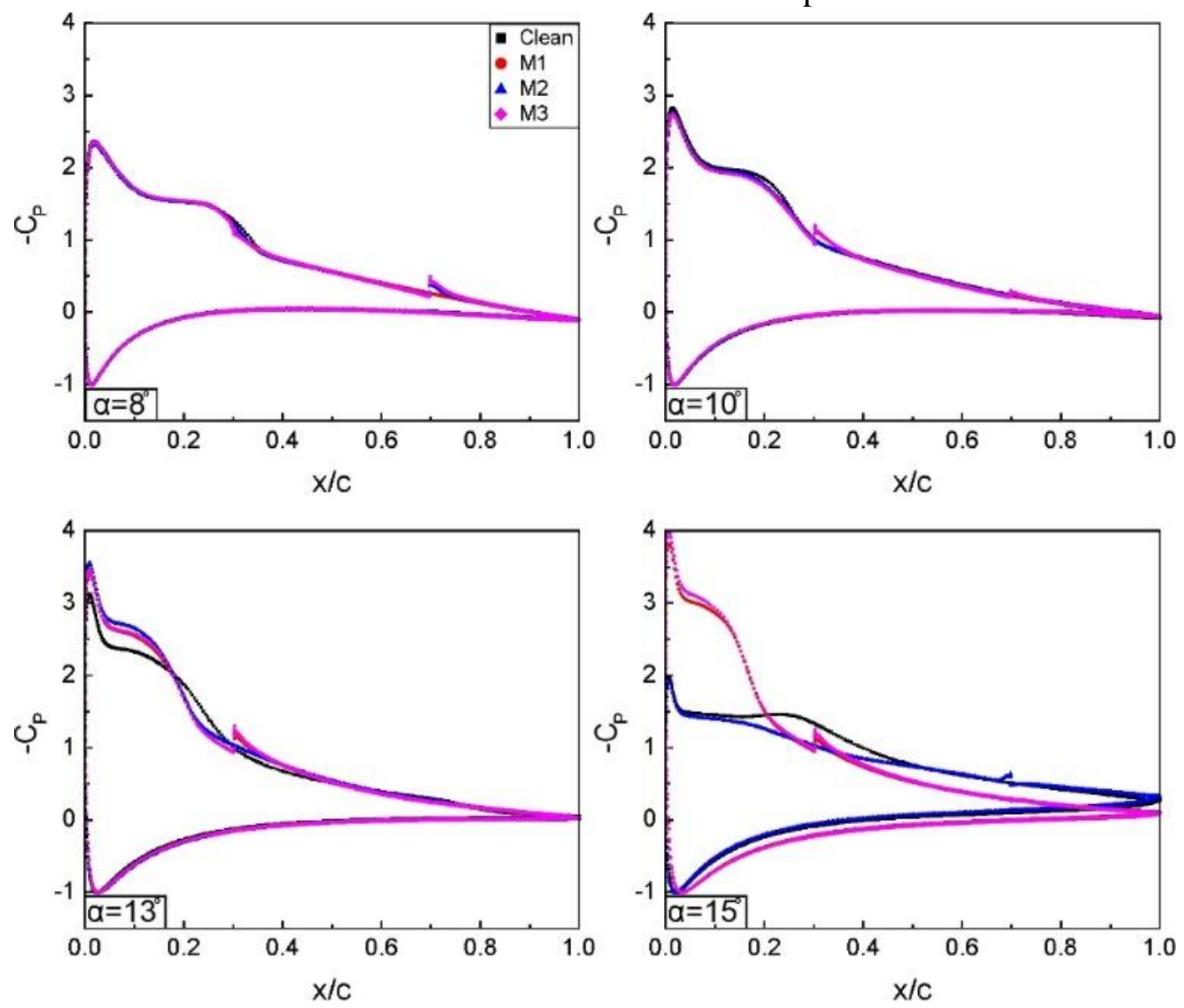

Figure 8. Distribution of the reverse pressure coefficient around the airfoil for all models at various angle of attacks 


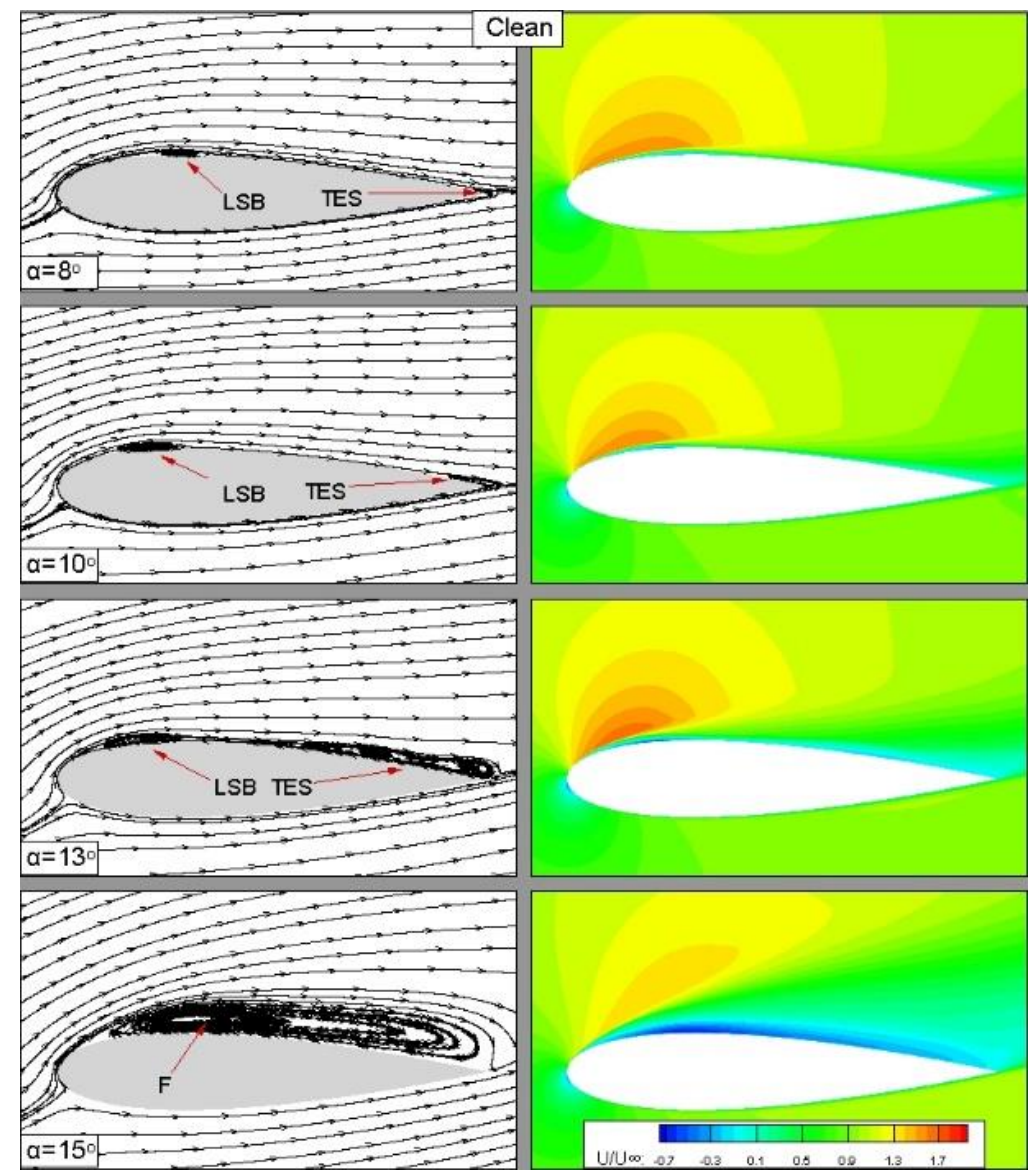

Figure 9. Streamline topologies and stream-wise velocity contours for clean airfoil at different angle of attacks

Figure 10 shows streamline topologies for M1, M2 and M3 at $\alpha=8^{\circ}, 10^{\circ}, 13^{\circ}$ and $15^{\circ}$ in order to demonstrate the effect of riblet on the flow structure around the airfoil. In the figure, each column presents different model while each row show different angle of attack. At $\alpha=8^{\circ}$, the control element (riblet) has insignificant effect on the streamline topology when compared to clean airfoil. With the increasing angle of attack, laminar separation bubble is suppressed and prevent to move toward leading edge. At $\alpha=13^{\circ}$, the size of trailing edge separation of M2 and M3 is smaller than the clean airfoil since located riblet at the $x / c=0.7$ prevents moving of trailing edge separation. On the other hand, it is observed that the size of LSB is smaller than the clean airfoil for M1. Due to the suppression of LSB and TES, an increase in the lift coefficient of M1, M2 and M3 is obtained at $\alpha=13^{\circ}$. At $\alpha=15^{\circ}$, it is observed that riblet located at the $\mathrm{x} / \mathrm{c}=0.3$ dominant on the streamline topology. It is clearly seen that the size of LSB of M1 and M3 is smaller than clean airfoil. As a result of this situation the merging of the LSB with the TES prevent, therefore stall is delayed. A large recirculation region is observed for M2 due to the stall. Obtained results indicate that the effect of installing riblet at $\mathrm{x} / \mathrm{c}=0.3$ and installing at both $\mathrm{x} / \mathrm{c}=0.3$ and 0.7 is nearly same. 

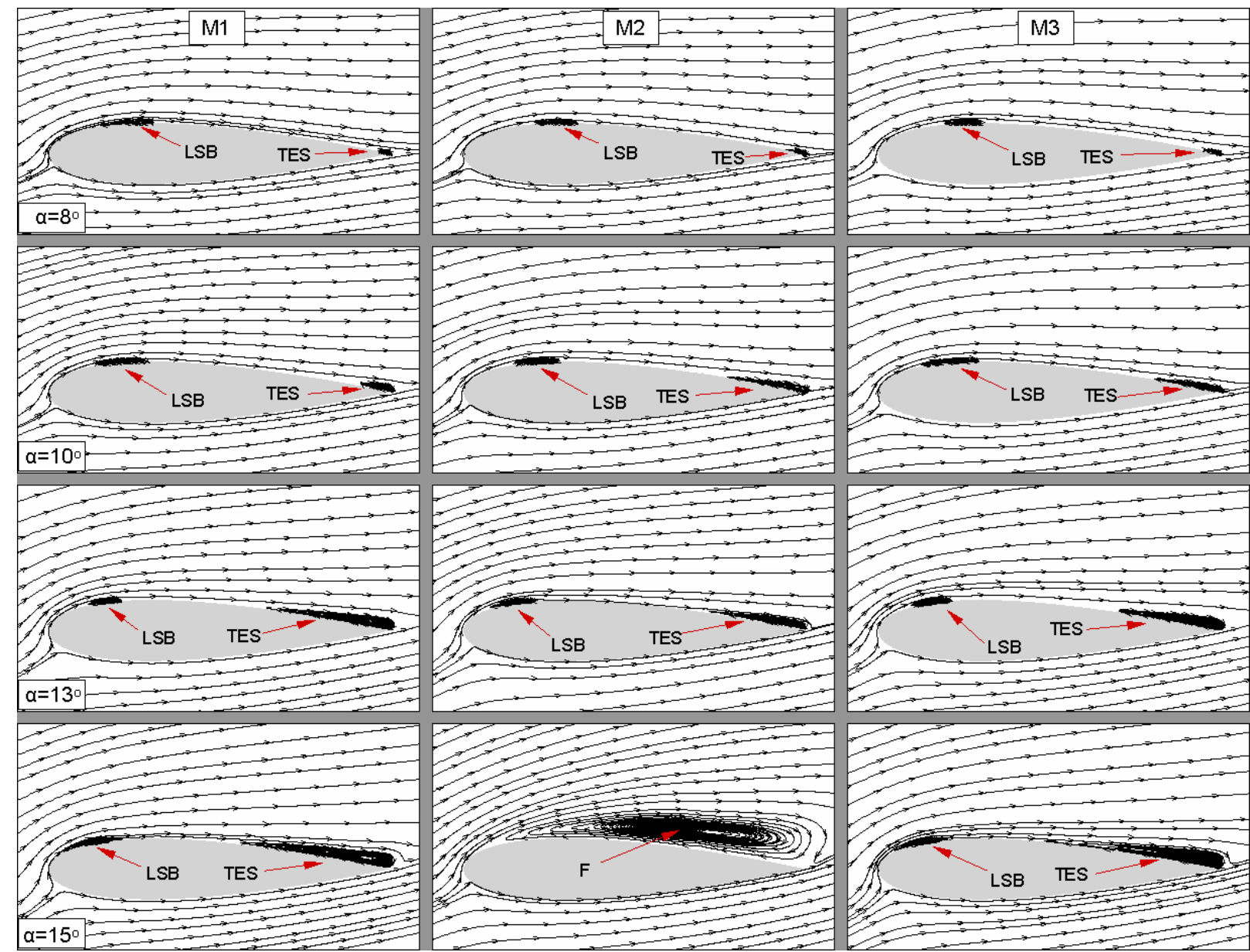

Figure 10. Streamline topologies of M1, M2 and M3 models at different angle of attacks

\section{CONCLUSION}

This numerical study reports the effect of riblet on the suppression of laminar separation bubble of NACA 0018 airfoil. Numerical solution was performed at Reynolds number of $\mathrm{Re}=100000$ for different angle of attacks. The riblet was used as a passive flow control element. Riblet was located at chord wise section of $\mathrm{x} / \mathrm{c}=0.3$ and 0.7 , separately. Also, two riblets were installed together at that locations. Obtained results indicate that use of riblet has remarkable effect for flow structure around airfoil. At angle of attack $\alpha=10^{\circ}$, the lift coefficient, $\mathrm{C}_{\mathrm{L}}$ is increased for all model with compared to base model which is clean NACA 0018. Moreover, stall angle is delayed with $2^{\circ}$ for M1 and M3 with compared to clean model due to suppression of LSB and separation on the trailing edge. It is expected the riblet could be used as an alternative passive flow control technique.

\section{Conflict of Interest}

The article authors declare that there is no conflict of interest between them.

\section{Author's Contributions}

The authors declare that they have contributed equally to the article

\section{REFERENCES}

Beyhaghi S, Amano RS, 2018. A parametric study on leading-edge slots used on wind turbine airfoils at various angles of attack, Journal of Wind Engineering and Industrial Aerodynamics 175, 43-52.

Caram JM, Ahmed A, 1992. Development of the wake of an airfoil with riblets. AIAA journal, 30(12), 28172818 . 
Chamorro LP, Arndt REA, Sotiropoulos F, 2013. Drag reduction of large wind turbine blades through riblets: evaluation of riblet geometry and application strategies, Renewable Energy (50).

Demir H, Genç MS, 2017. An experimental investigation of laminar separation bubble formation on flexible membrane wing. European Journal of Mechanics / B Fluids, 65, 326-338.

Fatehi M, Ahmadabadi MN, Nematollahi O, Minaiean A, Kim KC, 2019. Aerodynamic performance improvement of wind turbine blade by cavity shape optimization, Renewable Energy, 132, 773-785.

Genç MS, Karasu I, Açıkel HH, 2012. An experimental study on aerodynamic of NACA2415 aerofoil at low Re numbers, Experimental Thermal and Fluid Science, 39, 252-264.

Genç MS, Karasu I, Açıkel HH, Akpolat MT, 2012. Low Reynolds Number Aerodynamics and Transition, InTechOpen.

Han M, Lim HC, Jang YG, Lee SS, Lee SJ, 2003. Fabrication of a micro-riblet film and drag reduction effects on curved objects, TRANSDUCERS '03. 12th International Conference on Solid-State Sensors, Actuators and Microsystems, Boston.

Istvan MS, Kurelek JW, Yarusevych S, 2017. Turbulence intensity effects on laminar separation bubbles formed over an airfoil, AIAA Journal 56.4 (2018): 1335-1347.

Janmian L, Feng G, Can H, 2013. Numerical study of separation on the trailing edge of a symmetrical airfoil at a low Reynolds number, Chinese Journal of Aeronautics, 26(4), 918-925.

Koca K, Genç MS, Açıkel HH, 2016. Experimental Investigation of Surface Roughness Effect over Wind Turbine Airfoil, 1th International Mediterranean Science and Engineering Congress, Adana.

Lee SJ, Jang YG, 2005. Control of flow around a NACA 0012 airfoil with a micro-riblet film, Journal of fluids and structures 20(5), 659-672.

Ricci R, Montelpare S, 2005. A quantitative IR thermographic method to study the laminar separation bubble phenomenon. International Journal of Thermal Sciences, 44, 709-719.

Rinoie K, Okuno M, Sunada Y, 2009. Airfoil stall suppression by use of a bubble burst control plate. AIAA Journal 47(2), 322-330.

Sareen A, Deters RW, Henry SP, Selig MS, 2011. Drag reduction using riblet film applied to airfoils for wind turbines, 49th AIAA Aerospace Sciences Meeting Including the New Horizons Forum and Aerospace Exposition, Orlando.

Sefiddashti MN, Ahmadabadi MN, Rizi BS, 2018. Experimental study of effects of circular-cross-section riblets on the aerodynamic performance of Risø airfoil at transient flow regime. Journal of Mechanical Science and Technology 32(2), 709-716.

Seshagiri A, Cooper E, Traub LW, 2009. Effects of vortex generators on an airfoil at low Reynolds numbers, Journal of Aircraft 46(1), 116-122.

Sundaram S, Viswanath PR, Rudrakumar S, 1996. Viscous drag reduction using riblets on NACA 0012 airfoil to moderate incidence. AIAA Journal, 34(4), 676-682.

Walters DK, Leylek JH, 2004. A new model for boundary layer transition using a single-point RANS approach. J. Turbomach., 126(1), 193-202.

Yarusevych S, Sullivan PE, Kawall JG, 2009. On vortex shedding from an airfoil in low-Reynolds-number flows, Journal of Fluid Mechanics, 632, pp.245-271.

Zhang W, Hain R, Kähler CJ, 2008. Scanning PIV investigation of the laminar separation bubble on a SD7003 airfoil, Experiments in Fluids, 45, 725-743. 